\title{
Preclinical validation of Notch therapeutics for cancer treatment
}

Citation for published version (APA):

Yahyanejad, S. (2015). Preclinical validation of Notch therapeutics for cancer treatment. [Doctoral Thesis, Maastricht University]. Datawyse / Universitaire Pers Maastricht. https://doi.org/10.26481/dis.20151015sy

Document status and date:

Published: 01/01/2015

DOI:

10.26481/dis.20151015sy

Document Version:

Publisher's PDF, also known as Version of record

\section{Please check the document version of this publication:}

- A submitted manuscript is the version of the article upon submission and before peer-review. There can be important differences between the submitted version and the official published version of record.

People interested in the research are advised to contact the author for the final version of the publication, or visit the DOI to the publisher's website.

- The final author version and the galley proof are versions of the publication after peer review.

- The final published version features the final layout of the paper including the volume, issue and page numbers.

Link to publication

\footnotetext{
General rights rights.

- You may freely distribute the URL identifying the publication in the public portal. please follow below link for the End User Agreement:

www.umlib.nl/taverne-license

Take down policy

If you believe that this document breaches copyright please contact us at:

repository@maastrichtuniversity.nl

providing details and we will investigate your claim.
}

Copyright and moral rights for the publications made accessible in the public portal are retained by the authors and/or other copyright owners and it is a condition of accessing publications that users recognise and abide by the legal requirements associated with these

- Users may download and print one copy of any publication from the public portal for the purpose of private study or research.

- You may not further distribute the material or use it for any profit-making activity or commercial gain

If the publication is distributed under the terms of Article $25 \mathrm{fa}$ of the Dutch Copyright Act, indicated by the "Taverne" license above, 


\section{Propositions \\ Belonging to the thesis entitled \\ "Preclinical validation of Notch therapeutics for cancer treatment" \\ Sanaz Yahyanejad \\ 15 October, 2015}

1. NOTCH4 is functionally very different from other NOTCH receptors and despite our very intense study and the others on understanding its activation mechanism, there still remains a lot of unanswered questions. (this thesis)

2. The findings of this thesis offer an opportunity to develop new treatment strategies for the treatment of glioblastoma. (this thesis)

3. There is a great need to develop safe and efficient NOTCH-based therapies. (this thesis)

4. An image-guided precision irradiator and a dedicated treatment planning system are required for accurate irradiation in preclinical studies to more closely mimic clinical practice. (this thesis)

5. Understanding the Notch expression status of different tumors would be invaluable for scheduling an appropriate treatment on patients who will likely benefit from Notch targeted therapies. (Valorization)

6. Science is always wrong, it never solves a problem without creating ten more. (George Bernard Shaw)

7. Climb mountains not so the world can see you, but so you can see the world. (David McCullough)

8. Some beautiful paths cannot be discovered without getting lost. (Erol Ozan)

9. The real voyage of discovery consists not in seeking new landscapes, but in having new eyes." (Marcel Proust)

10. When all the details fit in perfectly, something is probably wrong with the story. (Charles Baxter)

11. Choose a job you love, and you will never have to work a day in your life. (Confucius) 